University of Nebraska - Lincoln

DigitalCommons@University of Nebraska - Lincoln

Faculty Papers and Publications in Animal

Science

Animal Science Department

1997

\title{
Comparison of USDA Quality Grade with Tendertec for the Assessment of Beef Palatability
}

M. H. George

Colorado State University, Fort Collins

J.D. Tatum

H. G. Dolezal

Oklahoma State University, Stillwater

J. B. Morgan

Oklahoma State University, Stillwater

J. M. Wise

USDA Standardization Branch, Agricultural Marketing Service

See next page for additional authors

Follow this and additional works at: https://digitalcommons.unl.edu/animalscifacpub

Part of the Animal Sciences Commons

George, M. H.; Tatum, J.D.; Dolezal, H. G.; Morgan, J. B.; Wise, J. M.; Calkins, Chris R.; Gordon, T.; Reagan, J. O.; and Smith, G. C., "Comparison of USDA Quality Grade with Tendertec for the Assessment of Beef Palatability" (1997). Faculty Papers and Publications in Animal Science. 588.

https://digitalcommons.unl.edu/animalscifacpub/588

This Article is brought to you for free and open access by the Animal Science Department at DigitalCommons@University of Nebraska - Lincoln. It has been accepted for inclusion in Faculty Papers and Publications in Animal Science by an authorized administrator of DigitalCommons@University of Nebraska - Lincoln. 


\section{Authors}

M. H. George, J.D. Tatum, H. G. Dolezal, J. B. Morgan, J. M. Wise, Chris R. Calkins, T. Gordon, J. O. Reagan, and G. C. Smith 


\title{
Comparison of USDA Quality Grade with Tendertec for the Assessment of Beef Palatability ${ }^{1}$
}

\author{
M. H. George², J. D. Tatum, H. G. Dolezal3, J. B. Morgan33, J. W. Wise4, \\ C. R. Calkins5, T. Gordon6, J. O. Reagan7, and G. C. Smith
}

\author{
Department of Animal Sciences, Colorado State University, Fort Collins 80523-1171
}

\begin{abstract}
Carcasses $(n=265)$ selected to differ in USDA yield grade were evaluated by expert graders and assessed for tenderness with the Tendertec Mark III Beef Grading Instrument. Tendertec measurements were collected on longissimus lumborum muscles in both sides of each carcass. During fabrication of each left carcass side, a rib section (later converted into three steaks) was removed for aging and subsequent sensory panel evaluation at $14 \mathrm{~d}$ and for Warner-Bratzler shear force measurements at 14 and $28 \mathrm{~d}$. Correlation coefficients for repeatability of Tendertec output variables, between left and right carcass sides, were .57, .44, .70, and .65 for Area-2, Area-2B, Power-2, and Power-2B, respectively. Correlations between Tendertec output variables and Warner-Bratzler shear force evaluations performed on steaks aged 14 or $28 \mathrm{~d}$ were not different from zero.
\end{abstract}

Sensory panel ratings for amount of connective tissue were correlated $(P<.01)$ with Tendertec output variables Area-2 and Area-2B ( $r=-.168$ and -.154 , respectively), and ratings for overall tenderness were correlated $(P<.05)$ with the Area-2 output variable ( $r=-.131)$ but the coefficients were very low. Segregation analysis, using Tendertec output variables Area-2 and Power-2, significantly $(P<.05)$ stratified sensory panel ratings for connective tissue amount and overall tenderness. Even though the Tendertec probe detected some differences in connective tissue contributions to rib steak tenderness, it was not better than USDA quality grade at segmenting A-maturity carcasses into anticipated tenderness outcomes, and thus its applicability as a grading instrument may be limited to use on more mature beef carcasses.

Key Words: Quality Grading, Tenderness, Probes, Palatability

J. Anim. Sci. 1997. 75:1538-1546

\section{Introduction}

A number of literature reviews and scientific papers include concern regarding the limitations of USDA quality grades for predicting tenderness in specific beef carcasses (Briskey and Bray, 1964; Parrish, 1974; J ones and Tatum, 1994; Wheeler et al., 1994).

\footnotetext{
${ }^{1}$ The authors would like to thank Geoff J ohnston of Tendertec International, Bemboka, NSW 2550 Australia, for kindly providing the Tendertec unit used in the present study.

${ }^{2}$ To whom correspondence should be addressed.

${ }^{3}$ Dept. of Anim. Sci., Oklahoma State Univ., Stillwater 74078-0425.

${ }^{4}$ USDA Standardization Branch, Agricultural Marketing Service, 14th and Independence, Washington, DC 20090-6456.

${ }^{5}$ Dept. of Anim. Sci., University of Nebraska, Lincoln 68583-0908.

${ }^{6}$ Meat Research Corp., 26 College Avenue, Sydney, NSW 2000 Australia.

${ }^{7} \mathrm{~N}$ ational Cattlemen's Beef Association, Englewood, CO 80155.

Received September 18, 1996.

Accepted February 11, 1997.
}

Moreover, during the National Beef Tenderness Symposium (NCA, 1994) it was revealed that 1 ) one in every four steaks is less than desirable in tenderness and overall palatability (Smith et al., 1992), 2) one tough carcass may affect as many as 542 consumers (Harris and Savell, 1993), and 3) beef industry leadership is adamant about increasing market-share, with increasing beef tenderness being key to this change in positioning. From the latter symposium, the National Beef Tenderness Plan was developed and included the recommendation, among others, to encourage the development of a rapid test for tenderness of carcasses. A National Beef Instrument Assessment Symposium (National Live Stock and Meat Board, 1994) concluded that video image analysis, total body electrical conductivity, and Tendertec were, in that order, the most deserving technologies for which applied research should be conducted. The present study was conducted to compare the effectiveness of USDA quality grade factors and Tendertec, as an online tenderness grading instrument, for use in predicting tenderness of beef. 


\section{Experimental Procedures}

Carcasses ( $n=240$ beef; $n=25$ dairy) selected to differ in USDA yield grade were evaluated at $36 \mathrm{~h}$ postmortem by expert graders and were assessed for tenderness with the Tendertec Mark III Beef Grading Instrument (U.S. Patent No. 4,939,927). Expert graders (two from universities and one from USDA, Agricultural Marketing Service) took as long as was necessary to assign values for skeletal maturity, lean maturity, overall maturity, marbling score (with use of the marbling picture cards) and quality grade (to the nearest .10 of a grade) to each carcass side (the left side) designated for subsequent fabrication. The values for each trait recorded for each of the expert graders were then averaged, and the mean was reported for subsequent statistical analyses.

Carcasses were then assessed with the Tendertec Mark III Beef Grading instrument (Tendertec International, Bemboka, NSW Australia), an electromechanical penetrometer, armed with a $14-\mathrm{cm}$ piston and pause stops to control insertion velocity at 4 and $6 \mathrm{~cm}$ of carcass insertion. In total, the probe tip penetrates to a predetermined depth of $8 \mathrm{~cm}$. The probe tip of the Tendertec was inserted perpendicularly between the dorsal spinous processes of thoracic and lumbar vertebra (T12-T13, T13-L1, and L1-L 2) through the multifidus dorsi and into the longissimus lumborum. To initiate insertion, force is applied to the piston by a spring and a second piston is advanced by the trigger assembly. Scales associated with the first and second piston measure the depth of penetration of the probe and the force required for penetration.

Six Tendertec readings (three per side) were recorded for each of 259 of the carcasses, but six carcasses had only one side probed, and thus had three Tendertec readings each. Carcass temperatures ranged between 1.5 and $4.0^{\circ} \mathrm{C}$ at the time of the Tendertec assessment. Immediately following the collection of the Tendertec readings, data were transferred from the Tendertec to a computer for storage and analysis.

During fabrication of the left side of each carcass, a rib section (posterior end, approximately $12.0 \mathrm{~cm}$ long) was removed, vacuum-packaged, and transported to the Colorado State University Meat Science Laboratory. This rib section was further fabricated to yield three 2.54-cm-thick steaks; two were aged (one for $14 \mathrm{~d}$ and one for $28 \mathrm{~d}$ ) and used for WarnerBratzler shear force measurements, and one was aged for $14 \mathrm{~d}$ and used for sensory panel evaluation. The three steaks were frozen and stored at $-27^{\circ} \mathrm{C}$ until subsequent testing was done.

Sensory Evaluation. Steaks were thawed in a $4^{\circ} \mathrm{C}$ cooler for $24 \mathrm{~h}$ before cooking on a Hobart Char Broiler, model CB51 (Hobart Corp., Troy, OH). During broiling, steaks were turned at $4,8,11$, and, if necessary, $14 \mathrm{~min}$ until they reached a final internal temperature of $70^{\circ} \mathrm{C}$. Steak internal temperature was monitored using a Atkins thermocouple (model 31308-KF ; Atkins Technical, Gainesville, FL) Steaks were cut into cubes $(1.00 \mathrm{~cm} \times 1.00 \mathrm{~cm} \times$ steak thickness) and presented warm, in a darkened room lit by soft red lights, for trained sensory panel evaluation (Cross et al., 1978). Sensory panelists ( $n=$ 8 ) scored steaks for muscle fiber tenderness, amount of connective tissue, overall tenderness, juiciness, and beef flavor intensity on 8-point scales ( $8=$ extremely tender, none, extremely tender, extremely juicy, and extremely intense; 1 = extremely tough, abundant, extremely tough, extremely dry, and extremely bland).

Shear Force Measurement. Steaks were randomly selected, by date of fabrication and aging period, and prepared as described above for sensory evaluation. Following cooking, steaks were cooled to room temperature (approximately $18^{\circ} \mathrm{C}$ ). Cores $(\mathrm{n}=8 ; 1.27 \mathrm{~cm}$ diameter) were removed parallel to the longitudinal orientation of the muscle fibers and sheared once, to measure peak force, using a Warner-Bratzler shear (WBS) force instrument.

Statistical Analyses. Analyses of means, ranges, and standard deviations for variables and simple correlation coefficients between and among Tendertec output variables; expert grader assessments of skeletal maturity, lean maturity, marbling score and quality grade; sensory panel ratings; and, WBS force values were computed using the correlation procedure of SAS (1991). Expert grader quality grades and Tendertec output variable data segregation were performed using the frequency procedure of SAS (1991). Steaks were further grouped using values for 14-d shear force, sensory panel ratings for muscle fiber tenderness, connective tissue amount, and overall tenderness, expert grader quality grade, and Tendertec output variables. The ANOVA were performed on the grouped data, and significant means were separated using the PDIFF procedure of SAS (1991). Maximum $\mathrm{R}^{2}$ stepwise regression (SAS, 1991) was used to identify regression models utilizing expert grader quality grade factors and quality grade, and Tendertec output variables.

\section{Results and Discussion}

Most carcasses were classified as " $A$ " in maturity, implying they were from animals that were less than 30 mo of age at harvest (Table 1). Mean marbling scores assigned by expert graders to left carcass sides ranged from traces ${ }^{40}$ (carcass grade of U.S. Standard) to slightly abundant ${ }^{13}$ (carcass grade of U.S. Prime). Expert Graders assigned five carcasses to the U.S. Standard quality grade and one carcass to the U.S. Prime quality grade, the remainder of the carcasses were U.S. Choice or U.S. Select. As anticipated, WBS force means decreased $(P<.05)$ as the aging period (postmortem) was increased from 14 to $28 \mathrm{~d}$. 
Table 1. Means, standard deviations, and minimum/maximum values for WarnerBratzler shear force values, sensory panel ratings, expert grader quality grade factors, expert grader quality grade, and Tendertec output variables

\begin{tabular}{|c|c|c|c|c|}
\hline Variable & Mean & SD & Minimum & Maximum \\
\hline $\begin{array}{l}\text { Expert grader skeletal maturity }{ }^{a} \\
\text { Expert grader lean maturity } \\
\text { Expert grader marbling } \\
\text { Expert grader quality grade }\end{array}$ & $\begin{array}{r}161.47 \\
155.52 \\
419.30 \\
3.53\end{array}$ & $\begin{array}{r}16.84 \\
14.46 \\
81.32 \\
.54\end{array}$ & $\begin{array}{r}126.70 \\
126.70 \\
240.00 \\
2.00\end{array}$ & $\begin{array}{r}296.70 \\
226.70 \\
713.30 \\
5.00\end{array}$ \\
\hline $\begin{array}{l}\text { WBS-14 } \\
\text { WBS-28 }\end{array}$ & $\begin{array}{l}2.40 \\
2.12\end{array}$ & $\begin{array}{l}.69 \\
.54\end{array}$ & $\begin{array}{l}1.25 \\
1.17\end{array}$ & $\begin{array}{l}5.24 \\
5.13\end{array}$ \\
\hline $\begin{array}{l}\text { MFT rating } \\
\text { CTA rating } \\
\text { OT rating } \\
\text { O } \\
\text { J UI rating } \\
\text { FI rating }\end{array}$ & $\begin{array}{l}4.90 \\
4.67 \\
4.64 \\
4.82 \\
4.89\end{array}$ & $\begin{array}{l}.81 \\
.75 \\
.83 \\
.41 \\
.24\end{array}$ & $\begin{array}{l}2.43 \\
2.14 \\
2.14 \\
3.57 \\
4.29\end{array}$ & $\begin{array}{l}6.83 \\
6.21 \\
6.43 \\
5.83 \\
5.67\end{array}$ \\
\hline $\begin{array}{l}\text { Tendertec Probe Area-2 } \\
\text { Tendertec Probe Area-2B } \\
\text { Tendertec Probe Power-2 } \\
\text { Tendertec Probe Power-2B }\end{array}$ & $\begin{array}{r}13,723 \\
6,454 \\
36.69 \\
25.82\end{array}$ & $\begin{array}{r}2,619 \\
1,286 \\
9.09 \\
7.18\end{array}$ & $\begin{array}{l}8,689 \\
3,573 \\
21.13 \\
12.60\end{array}$ & $\begin{array}{r}21,762 \\
10,952 \\
66.56 \\
54.63\end{array}$ \\
\hline \multicolumn{5}{|c|}{ 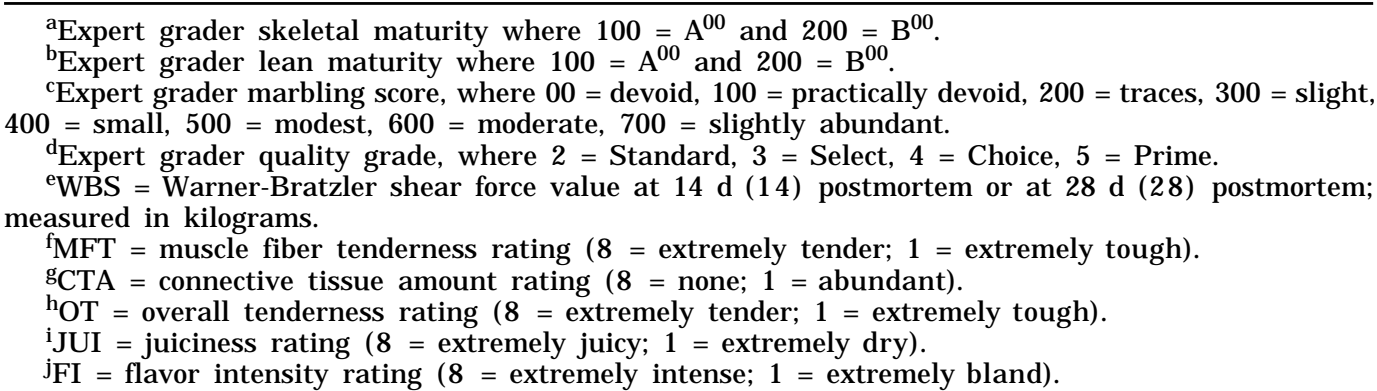 } \\
\hline
\end{tabular}

Examination of the sensory panelist data suggests that the majority of the steaks were acceptable in ratings for tenderness, juiciness, and flavor intensity; however, mean panel scores for overall tenderness of individual steaks ranged from 2.14 to 6.43 .

Tendertec output variables were extracted from force measurements that were collected between piston pauses, such that the probe tip had passed through the multifidus dorsi and through the medial perimysium of the longissimus lumborum before the first probe pause. During the entire insertion period (less than $2 \mathrm{~s}$ ), Tendertec force readings are collected by the probe every $75 \mu \mathrm{s}$ and plotted against time and probe insertion distance, for a possible maximum of 2,000 paired force and distance measurements (Figure 1). Probe parameters between the first and second pause were subsequently extracted to yield the area under this portion of the force curve (Area-2), modified (Area-2B), or Area divided by the time taken for the probe tip to progress into the muscle, which equals the distance between the first and second pauses (Power-2 and Power-2B). This position-based and time-based recording system was designed to overcome measurement disorder and recoil influences caused by piercing strong connective tissue sheaths, such as encompass the longissimus lumborum (Swatland et al., 1994).

Correlation coefficients for the Tendertec output variables between the left and the right sides of carcasses were .57, .44, .70, and .65 (all $\mathrm{P}<.001$ ) for Area-2, Area-2B, Power-2, and Power-2B, respectively (data not presented in tabular form). These correlations among Tendertec output variables for carcass sides suggest that such readings are moderately repeatable. Moreover, the addition of time-period components, and thus probe tip velocity (Power- 2 and Power-2B), improved the Tendertec output variable correlations between carcass sides as compared to area-based (Area-2 and Area-2B) variables alone.

Warner-Bratzler shear force values for steaks aged 14 or $28 \mathrm{~d}$ were correlated $(P<.001)$ with panelist ratings for muscle fiber tenderness, connective tissue amount, and overall tenderness (Table 2). The latter correlations decreased numerically as steaks were aged longer (28 vs $14 \mathrm{~d}$ postmortem) but they remained significant at the .001 level. Many researchers, including Smith et al. (1978), have demonstrated a characteristic improvement in beef tenderness during postmortem aging in response to myofibrillar protein degradation by endogenous proteases. Stanton and Light $(1988,1990)$ concluded that there was some effect of proteolytic processing on perimysial and endomysial collagen during the postmortem conditioning period; however, Koohmariae (1992) reported that myofibrillar fragmentation, rather than collagen concentration, was responsible for tenderness variations observed in A-maturity carcasses. 


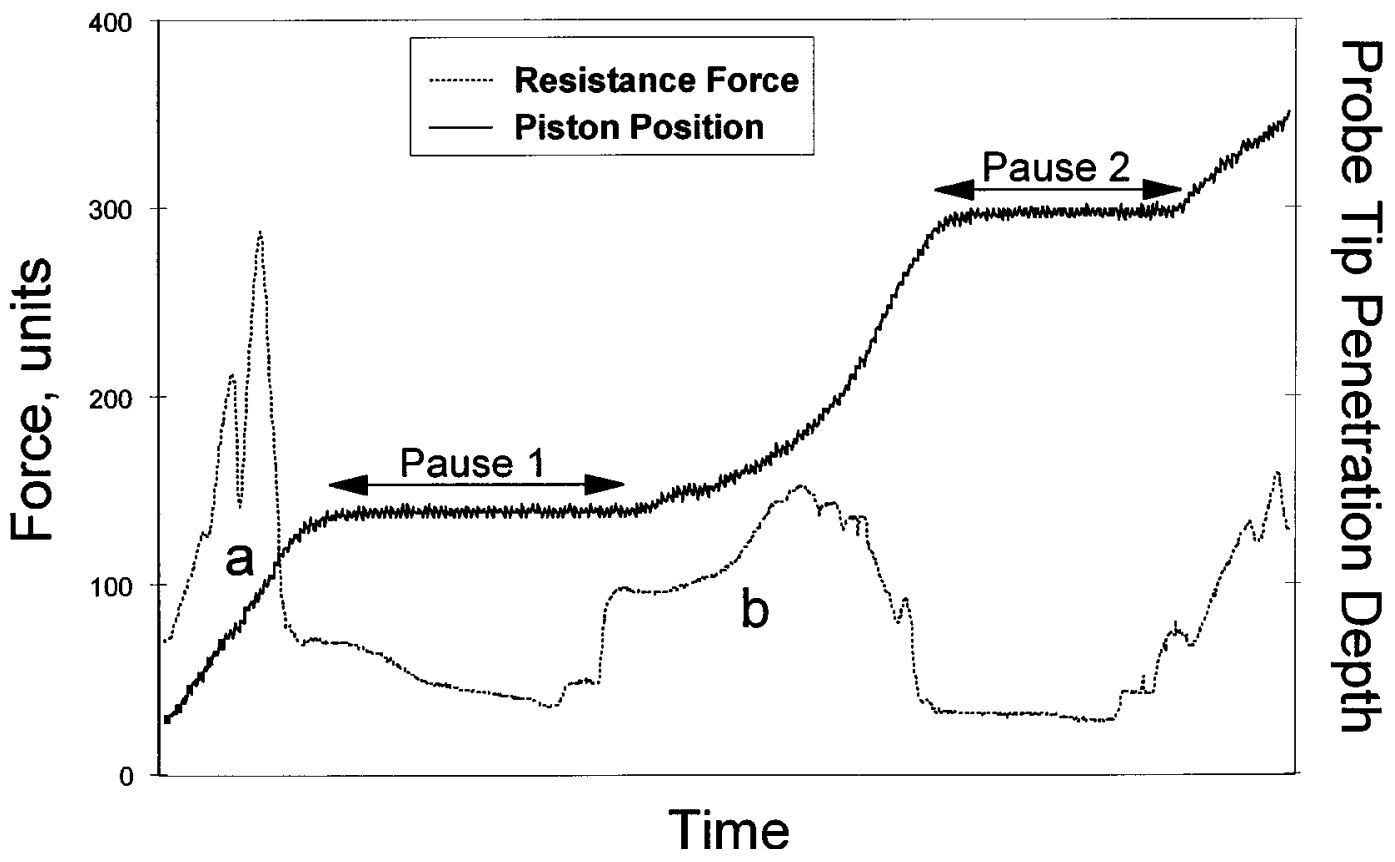

Figure 1. Schematic of a Tendertec generated force curve plotted relative to piston position (probe tip depth within the longissimus) and time. ${ }^{a}$ Represents measurement noise associated with penetration of the longissimus epimysial sheath. ${ }^{b}$ Represents the actual area under the curve used in analyses reported to generate Tendertec output variables. Pause 1 = period probe tip remains stationary, following entry into the longissimus, and signifies the commencement of the force assessment period. Pause $2=$ period probe tip remains stationary and signifies the end of the measurement period.

Although there were no correlations different from zero $(\mathrm{P}>.05)$ between expert grader skeletal maturity score and WBS force values or sensory panel ratings, there were correlations $(P<.05)$ between expert grader lean maturity scores and WBS force values at $d 14$ and 28 and between expert grader lean maturity score and sensory panel ratings for muscle fiber tenderness, connective tissue amount, and overall tenderness (Table 3). Expert grader quality grade was significantly but lowly correlated $-.142,-.141$,
$.206, .138$, and .198 with rib steak shear force value at d 14, shear force value at d 28, muscle fiber tenderness rating, connective tissue amount rating, and overall tenderness rating, respectively, and expert grader marbling score was correlated $(P<.05)-.215$, $-.222, .222, .149$, and .202 with these same traits, respectively.

Tendertec output variables Area-2 $(r=-.168)$ and Area-2B $(r=-.154)$ were correlated $(P<.01)$ with connective tissue amount rating (Table 3 ). Tendertec

Table 2. Correlation coefficients among Warner-Bratzler shear force values and sensory panel ratings for rib steaks

\begin{tabular}{lccccccc}
\hline \hline Variable & WBS-14 $^{\mathrm{a}}$ & $\mathrm{WBS}^{2} 8^{\mathrm{a}}$ & $\mathrm{MFT}^{\mathrm{b}}$ & $\mathrm{CTA}^{\mathrm{c}}$ & $\mathrm{OT}^{\mathrm{d}}$ & $\mathrm{JUI}^{\mathrm{e}}$ & $\mathrm{FI}^{\mathrm{f}}$ \\
\hline WBS-14 $^{\mathrm{a}}$ & 1.00 & $.576^{* * *}$ & $-.611^{* * *}$ & $-.621^{* * *}$ & $-.643^{* * *}$ & $-.156^{*}$ & .025 \\
WBS-28 $^{\mathrm{a}}$ & & 1.00 & $-.547^{* * *}$ & $-.535^{* * *}$ & $-.549^{* * *}$ & $-.198^{* *}$ & .079 \\
MFT $^{\mathrm{b}}$ & & & 1.00 & $.818^{* * *}$ & $.969^{* * *}$ & $.287^{* * *}$ & .007 \\
CTA $^{\mathrm{c}}$ & & & & 1.00 & $.894^{* * *}$ & $.130^{*}$ & -.101 \\
OT $^{\mathrm{d}}$ & & & & & 1.00 & $.258^{* * *}$ & .001 \\
J Ul $^{\mathrm{e}}$ & & & & & & 1.00 & $.392^{* * *}$ \\
FI $^{\mathrm{f}}$ & & & & & & & 1.00 \\
\hline
\end{tabular}

aWBS $=$ Warner-Bratzler shear force value at $14 \mathrm{~d}$ (14) postmortem or $28 \mathrm{~d}$ (28) postmortem.

bMFT $=$ muscle fiber tenderness rating ( $8=$ extremely tender; $1=$ extremely tough).

${ }^{\mathrm{C}} \mathrm{CTA}=$ connective tissue amount rating ( $8=$ none; $1=$ abundant).

${ }^{\mathrm{d}}$ OT $=$ overall tenderness rating ( $8=$ extremely tender; $1=$ extremely tough).

e UI = juiciness rating (extremely juicy; 1 = extremely dry).

$\mathrm{f}_{\mathrm{FI}}=$ flavor intensity rating ( 8 = extremely intense; $1=$ extremely bland).

$* P<.05$.

$* * \mathrm{P}<.01$.

$* * * \mathrm{P}<.001$ 
Table 3. Correlation coefficients among Warner-Bratzler shear force values, sensory panel ratings, expert grader quality grade factors, expert grader quality grades, and Tendertec output variables

\begin{tabular}{|c|c|c|c|c|c|c|c|}
\hline \multirow{2}{*}{$\begin{array}{l}\text { Quality grade and } \\
\text { Tendertec traits }\end{array}$} & \multicolumn{2}{|c|}{$\begin{array}{l}\text { Warner-Bratzler } \\
\text { shear force value }\end{array}$} & \multicolumn{5}{|c|}{ Sensory panel rating } \\
\hline & d 14 & d 28 & $\mathrm{MFT}^{\mathrm{a}}$ & $\mathrm{CTA}^{\mathrm{b}}$ & $\mathrm{OT}^{\mathrm{c}}$ & $J \cup I^{d}$ & $\mathrm{FI}^{\mathrm{e}}$ \\
\hline $\begin{array}{l}\text { Expert grader skeletal } \\
\text { maturity score }\end{array}$ & .070 & .027 & -.119 & -.104 & -.123 & .075 & .058 \\
\hline $\begin{array}{l}\text { Expert grader lean } \\
\text { maturity score } \\
\text { Expert grader }\end{array}$ & $.169 * *$ & $.138^{*}$ & $-.192^{* *}$ & $-.178 * *$ & $-.188^{* *}$ & .114 & .103 \\
\hline $\begin{array}{l}\text { marbling score } \\
\text { Expert grader }\end{array}$ & $-.215^{* * *}$ & $-.222 * * *$ & $.222^{* * *}$ & $-.149 *$ & $.202^{* *}$ & .104 & .079 \\
\hline quality grade & $-.142^{*}$ & $-.141^{*}$ & $.206^{* * *}$ & $.138 *$ & $.198^{* *}$ & .084 & .067 \\
\hline Tendertec Area-2 & -.041 & -.048 & -.083 & $-.168 * *$ & -.119 & .099 & -.080 \\
\hline Tendertec Area-2B & .031 & .066 & -.099 & $-.154 * *$ & $-.131 *$ & .029 & -.049 \\
\hline Tendertec Power-2 & -.090 & -.050 & -.022 & $-.122^{*}$ & -.062 & $.142^{*}$ & .010 \\
\hline Tendertec Power-2B & -.043 & .039 & -.034 & -.111 & -.064 & $.169 * *$ & .072 \\
\hline
\end{tabular}

aMFT = muscle fiber tenderness rating ( $8=$ extremely tender; $1=$ extremely tough).

${ }^{\mathrm{b}} \mathrm{CTA}=$ connective tissue amount rating ( $8=$ none; $1=$ abundant).

COT $=$ overall tenderness rating ( $8=$ extremely tender; $1=$ extremely tough $)$.

d UI = steak juiciness rating ( $8=$ extremely juicy; $1=$ extremely dry $)$.

eFI = flavor intensity rating ( 8 = extremely intense; 1 = extremely bland).

$* \mathrm{P}<.05$.

$* * \mathrm{P}<.01$.

$* * * \mathrm{P}<.001$.

output variable Area-2B was correlated $(P<.05)$ with panelist overall tenderness rating $(r=-.131)$ but there were no significant correlations between any of the Tendertec output variables and either WBS force values or muscle fiber tenderness ratings.

Overall, these results suggest that, in assessments of Iongissimus lumborum, the Tendertec is somewhat sensitive to amounts of connective tissue identified by sensory panelists in beef rib steaks; however, the Tendertec is less sensitive to muscle fiber tenderness components contributing to panelist-assessed tenderness. The latter finding is in agreement with Gordon (1994), who identified a relationship $\left(R^{2}=.78\right)$ between animal dentition and Tendertec output variables of carcasses from animals differing widely in chronological age. In the present study, there were no correlations $(P>.05)$ between any of the Tendertec output variables and either scores for skeletal maturity or lean maturity, as assessed by expert graders. The latter result may be attributable to the very small range in maturity of the carcasses selected for use in the present study.

Segregation analyses of steak WBS force measurements, steak sensory panel evaluation ratings, and carcass Tendertec output variables, based on 14-d shear values (either WBS $\leq 1.71 \mathrm{~kg}$, WBS $>1.71$ $<3.09$, or WBS $\geq 3.09 \mathrm{~kg}$ ), for beef rib steaks effectively $(P<.001)$ stratified $d-14$ and -28 WBS force values and sensory panelist ratings for muscle fiber tenderness, connective tissue amount, and overall tenderness but failed to meaningfully segregate Tendertec output variables (Table 4). Moreover, a similar segregation analysis using d-14 WBS force ratings (either WBS $<3.90 \mathrm{~kg}$, or WBS $\geq 3.90 \mathrm{~kg}$ ) failed $(P>.05)$ to stratify Tendertec output variables (data not presented in tabular form). However, when this segregation procedure was repeated, using panelists' ratings for overall tenderness on steaks aged for $14 \mathrm{~d}$, Tendertec output variables were separated (Table 4). Tendertec output variables Area2 and Area-2B were more effectively separated by panelists' ratings for overall tenderness $(P<.05)$ for steaks than were Tendertec output variables Power-2 and Power-2B $(P>.05)$. Similarly, segregation of steaks by panelist-assessed overall tenderness ratings, when steaks with 4.5 or higher ratings were considered "acceptable" and when steaks with mean ratings less than 4.5 were considered "tougher," was accomplished $(P<.05)$ by use of Tendertec output variables Area-2 and Area-2B (data not presented in tabular form). Combined, these data suggest that the Tendertec is somewhat capable of detecting tenderness differences associated with panelist ratings for overall tenderness.

Segregation of WBS force values and sensory panel tenderness ratings for steaks, using Tendertec output variables from carcasses, are presented in Table 5. Consistent with the nonsignificant correlations between Tendertec output variables and WBS force values, segregation analyses using Tendertec output variables were unable to stratify correctly WBS force values assessed at either 14 or $28 \mathrm{~d}$ postmortem. However, segregation of steaks into three groups from carcasses by Tendertec output variables Area- 2 and Power-2 (i.e., either the lower $16.5 \%$ of Tendertec Area-2 or Power-2 readings; the intermediate or middle $67 \%$ of Tendertec Area- 2 or Power- 2 readings; 
Table 4. Segregation analysis based on d-14 Warner-Bratzler shear force value and panelist ratings for overall tenderness for steak shear force values, steak sensory panel ratings, and carcass Tendertec output variables

\begin{tabular}{|c|c|c|c|c|c|}
\hline \multirow[b]{2}{*}{ Variable } & \multicolumn{3}{|c|}{ Warner-Bratzler shear force value ${ }^{a}$} & \multirow[b]{2}{*}{$P$} & \multirow[b]{2}{*}{ SE } \\
\hline & $\leq 1.71$ & $>1.71$ and $<3.09$ & $\geq 3.09$ & & \\
\hline WBS-14c & $1.56^{i}$ & $2.28^{h}$ & $3.82^{\mathrm{g}}$ & .0001 & .357 \\
\hline WBS-28c & $1.81^{\mathrm{i}}$ & $2.05^{\mathrm{h}}$ & $2.80^{\mathrm{g}}$ & .0001 & .459 \\
\hline $\mathrm{MFT}^{\mathrm{d}}$ & $5.47^{g}$ & $4.96^{\mathrm{h}}$ & $3.90^{\mathrm{i}}$ & .0001 & .696 \\
\hline CTA $^{\mathrm{e}}$ & $5.13^{9}$ & $4.75^{\mathrm{h}}$ & $3.67^{i}$ & .0001 & .640 \\
\hline $\mathrm{OT}^{\mathrm{f}}$ & $5.23^{9}$ & $4.72^{\mathrm{h}}$ & $3.55^{i}$ & .0001 & .706 \\
\hline Tendertec Area-2 & 14,282 & 13,664 & 13,439 & .338 & $2,617.6$ \\
\hline Tendertec Area-2B & 6,623 & 6,432 & 6,476 & .708 & $1,288.8$ \\
\hline Tendertec Power-2 & $40.80^{\circ}$ & $36.08^{\mathrm{k}}$ & $35.68^{\mathrm{k}}$ & .011 & 8.966 \\
\hline \multirow[t]{3}{*}{ Tendertec Power-2B } & $28.71^{\mathrm{j}}$ & $25.30^{\mathrm{k}}$ & $25.60^{k}$ & .029 & 7.111 \\
\hline & \multicolumn{3}{|c|}{ Overall tenderness rating ${ }^{b}$} & & \\
\hline & $\leq 3.80$ & $>3.80$ and $<5.47$ & $\geq 5.47$ & & \\
\hline WBS-14c & 3.249 & $2.28^{h}$ & $1.97^{i}$ & .0001 & .570 \\
\hline WBS-28c & $2.61^{\mathrm{g}}$ & $2.08^{h}$ & $1.70^{i}$ & .0001 & .469 \\
\hline$M F T^{d}$ & $3.62^{i}$ & $4.94^{\mathrm{h}}$ & $6.00^{9}$ & .0001 & .452 \\
\hline $\mathrm{CTA}^{\mathrm{e}}$ & $3.49^{i}$ & $4.75^{\mathrm{h}}$ & $5.54^{9}$ & .0001 & .485 \\
\hline $\mathrm{OT}^{\mathrm{f}}$ & $3.26^{i}$ & $4.70^{h}$ & $5.85^{9}$ & .0001 & .430 \\
\hline Tendertec Area-2 & 14,606 & $13,523^{\mathrm{k}}$ & $13,572^{k}$ & .038 & $2,595.8$ \\
\hline Tendertec Area-2B & 6,928 & $6,513^{k}$ & 6,126 & .011 & $1,268.3$ \\
\hline Tendertec Power-2 & 39.06 & 35.88 & 37.59 & .082 & 9.034 \\
\hline Tendertec Power-2B & 27.71 & 25.44 & 25.23 & .133 & 7.153 \\
\hline
\end{tabular}

aWarner-Bratzler shear force value, where $>1.71$ and $<3.09$ (= mean \pm 1 SD).

bPanelist overall tenderness rating, where $>3.80$ and $<5.47$ ( $=$ mean \pm 1 SD).

QWBS $=$ Warner-Bratzler shear force value $(\mathrm{kg})$ at $14 \mathrm{~d}(14)$ postmortem or at $28 \mathrm{~d}(28)$ postmortem.

dMFT = muscle fiber tenderness rating ( $8=$ extremely tender; $1=$ extremely tough $)$.

${ }^{e} \mathrm{CTA}=$ connective tissue amount rating ( 8 = none; 1 = abundant).

${ }^{\mathrm{f}} \mathrm{OT}=$ overall tenderness rating ( $8=$ extremely tender; $1=$ extremely tough).

ghi Means within a row lacking a common superscript letter differ $(P<.01)$.

${ }^{j k l}$ Means within a row lacking a common superscript letter differ $(P<.05)$.

and the highest $16.5 \%$ of Tendertec Area-2 or Power-2 readings) successfully sorted $(P<.05)$ the "more tender" from the "intermediate" and "tougher" rib steaks, as assessed by ratings for amount of connective tissue and overall tenderness. In this analysis, Tendertec was able to segregate successfully $16.5 \%$ of rib steaks that were significantly more tender from other categories of rib steaks ("acceptable" and "tougher"), but there was no measurable difference ( $P$ $>.05$ ) between steaks that Tendertec segregated as either "intermediate" or "tougher" rib steaks.

In an examination of the percentage of all carcasses with a Tendertec probe output variable Area-2 reading $\leq 9,200$ and from 9,201 to $11,600,33.33$ and $58.33 \%$ of carcasses identified, respectively, had a rib steak muscle fiber tenderness rating $>5.10$ (mean +1 SD), with no "tough" steaks (i.e., steaks with a muscle fiber tenderness rating $<3.70$ ) being identified within this range (Table 6). Similarly, 33.33 and $50.00 \%$ of carcasses scored by Tendertec Area-2 as $\leq 9,200$ or 9,201 to 11,600 had overall tenderness ratings $>5.10$; 0 and $2.08 \%$ of carcasses within these Tendertec Area2 ranges had "tough" steaks. Moreover, 60, 50, and $40 \%$ of carcasses scored by Tendertec Area-2B as $\leq$
4,500 units yielded steaks with muscle fiber tenderness rating, connective tissue amount rating, and overall tenderness rating $>5.10$, respectively. In this same analysis, 40,60 , and $60 \%$ of the carcasses that the Tendertec probe identified as having Area-2B readings $\geq 10,000$ had sensory ratings $<3.70$ (i.e., steaks considered "tough") for muscle fiber tenderness, connective tissue amount, and overall tenderness, respectively.

Tendertec may be able to detect differences in amount of connective tissue in beef steaks; however, the ability to identify incremental amounts of connective tissue is not sufficient for identifying the tougher vs the more tender rib steaks in this population of carcasses. This latter finding reflects the fact that all of these carcasses were of A-maturity, and differences in amount of connective tissue are not expected to be useful for detection of tougher rib steaks in this youthful population of carcasses. Koohmariae (1992) attributed the majority of variability in tenderness among steaks from A-maturity carcasses to differences in calpastatin activity expression on myofibrillar fragmentation, rather than to differences in connective tissue amount. 
Table 5. Segregation analysis based on carcass Tendertec output variables for steak shear force values and steak sensory panel ratings

\begin{tabular}{|c|c|c|c|c|c|}
\hline $\begin{array}{l}\text { Tendertec } \\
\text { output variable }\end{array}$ & $\begin{array}{l}\text { "Tender" } \\
\text { group }\end{array}$ & $\begin{array}{l}\text { "Intermediate" } \\
\text { group }\end{array}$ & $\begin{array}{l}\text { “Tough” } \\
\text { group }\end{array}$ & $P$ & SE \\
\hline \multicolumn{6}{|l|}{ Area-2a } \\
\hline WBS-14 & 2.26 & 2.46 & 2.24 & .070 & .686 \\
\hline WBS-28 & 2.08 & 2.15 & 2.00 & .263 & .534 \\
\hline$M^{\prime} T^{f}$ & 5.15 & 4.82 & 4.96 & .067 & .803 \\
\hline $\mathrm{CTA}^{\mathrm{g}}$ & $5.05^{\mathrm{i}}$ & $4.60^{\circ}$ & $4.61^{j}$ & .003 & .736 \\
\hline $\mathrm{OT}^{\mathrm{h}}$ & $4.98^{j}$ & $4.57^{1}$ & 4.64 & .019 & .823 \\
\hline \multicolumn{6}{|l|}{ Area- $2 \mathrm{~B}^{\mathrm{b}}$} \\
\hline WBS-14 & 2.25 & 2.43 & 2.38 & .323 & .690 \\
\hline WBS-28 & 2.08 & 2.14 & 2.14 & .601 & .536 \\
\hline MFT & 5.09 & 4.86 & 4.89 & .272 & .807 \\
\hline СТА & 4.87 & 4.65 & 4.52 & .121 & .747 \\
\hline OT & 4.88 & 4.60 & 4.58 & .160 & .829 \\
\hline \multicolumn{6}{|l|}{ Power-2c } \\
\hline WBS-14 & 2.38 & 2.44 & 2.18 & .115 & .688 \\
\hline WBS-28 & 2.10 & 2.16 & 1.94 & .092 & .532 \\
\hline $\mathrm{MFT}$ & $5.20^{k}$ & $4.81^{1}$ & $5.05^{\mathrm{kl}}$ & .016 & .789 \\
\hline CTA & $4.97^{\mathrm{k}}$ & $4.62^{1}$ & $4.62^{1}$ & .037 & .744 \\
\hline OT & $4.97^{k}$ & $4.56^{1}$ & $4.73^{\mathrm{kl}}$ & .023 & .823 \\
\hline \multicolumn{6}{|l|}{ Power-2B ${ }^{d}$} \\
\hline WBS-14 & 1.81 & 2.40 & 2.40 & .697 & .693 \\
\hline WBS-28 & 2.02 & 2.10 & 2.13 & .942 & .537 \\
\hline MFT & 4.71 & 5.01 & 4.81 & .152 & .805 \\
\hline СТА & $5.00^{k}$ & $4.83^{\mathrm{kl}}$ & $4.55^{\prime}$ & .014 & .741 \\
\hline OT & 4.50 & 4.79 & 4.54 & .055 & .826 \\
\hline
\end{tabular}

aTendertec output variable Area-2, where “Tender" group =Area-2 $\leq 11,104$; “I ntermediate" group => 11,104 and $<16,342$ (= Mean \pm 1 SD); "Tough" group = Area-2 $\geq 16,342$.

"Tendertec output variable Area-2B, where “Tender" group =Area-2B $\leq 5,178$; “I ntermediate" group => 5,178 and $<7,750$ (= Mean \pm 1 SD); "Tough" group = Area-2B $\geq 7,750$.

'Tendertec output variable Power-2, where "Tender" group =Power-2 $\leq 27.69$; "I ntermediate" group => 27.69 and $<45.69$ (= Mean \pm 1 SD); "Tough" group = Power-2 $\geq 45.69$.

'Tendertec output variable Power-2B, where "Tender" group =Power-2B $\leq 18.54$; "Intermediate" group $=>18.54$ and $<33.00$ (= Mean \pm 1 SD); "Tough" group = Power-2B $\geq 33.00$.

eWBS $=$ Warner-Bratzler shear force value at $14 \mathrm{~d}(14)$ postmortem or at $28 \mathrm{~d}$ (28) postmortem.

${ }^{\mathrm{A}} \mathrm{MFT}=$ muscle fiber tenderness rating $(8=$ extremely tender; $1=$ extremely tough $)$.

${ }^{\mathrm{g}} \mathrm{CTA}=$ connective tissue amount rating ( $8=$ none; $1=$ abundant).

${ }^{h}$ OT $=$ overall tenderness rating ( $8=$ extremely tender; $1=$ extremely tough).

i,jMeans within a row lacking a common superscript letter differ $(P<.01)$.

$k, l$ Means within a row lacking a common superscript letter differ $(P<.05)$.

Using expert grader quality grade to assign carcasses into four grades (Standard through Prime) successfully separated $(P<.01)$ Choice rib steaks as having lower Warner-Bratzler shear values at $d 14$ and $d 28$ than rib steaks from Select carcasses (Table 7). Similarly, rib steaks from Choice carcasses (as assigned by expert graders) had higher $(P<.01)$ ratings for muscle fiber tenderness and overall tenderness. Consistent with other authors (Wheeler et al., 1994), panelist ratings for juiciness, flavor intensity, and flavor desirability did not differ for rib steaks from Choice vs Select carcasses. Although concern has been reported about the limitations of quality grades for predicting tenderness of carcasses (Parrish, 1974; J ones and Tatum, 1994; Wheeler et al., 1994), quality grades, as assigned by expert graders, were, in the present study, useful for segregating carcasses according to their likelihood of yielding steaks differing in palatability and should continue to be used until a system is identified to augment or assist the current use of differences in maturity and marbling for such purpose.

As independent predictors of overall tenderness ratings, the variables of expert grader marbling score and expert grader quality grade were similar, having $\mathrm{R}^{2}$ values of .040, and .039, respectively (Table 8). Similarly, as independent predictors of d-14 WBS force values, expert grader marbling score, and expert grader quality grade had $\mathrm{R}^{2}$ values of .046 and .029 , respectively (data not presented in tabular form). Tendertec output variables were somewhat weaker predictors of overall tenderness ratings, having $\mathrm{R}^{2}$ values of .014, .017, .003, and .004 for Area-2, Area2B, Power-2, and Power-2B, respectively. The addition of expert grader quality grade or expert grader quality grade factors to Tendertec output variables Area-2 or Area-2B slightly increased the ability of the regression equation to predict overall tenderness ratings. Using 
Table 6. Percentage of carcasses within ranges of Tendertec output variables Area-2 or Area-2B that have longissimus steaks with palatability characteristics in certain numerical categories

\begin{tabular}{|c|c|c|c|c|c|c|c|c|}
\hline $\begin{array}{l}\text { Tendertec } \\
\text { variable }\end{array}$ & \multicolumn{2}{|c|}{ WBS-14 ${ }^{\mathrm{a}}$} & \multicolumn{2}{|c|}{$\mathrm{MFT}^{\mathrm{b}}$} & \multicolumn{2}{|c|}{ CTA $^{C}$} & \multicolumn{2}{|c|}{$\mathrm{OT}^{\mathrm{d}}$} \\
\hline \multicolumn{9}{|l|}{ Area-2 } \\
\hline $9,201-11,600$ & 18.75 & 2.08 & 58.33 & 0 & 47.92 & 2.08 & 50.00 & 2.08 \\
\hline $11,601-13,000$ & 9.68 & 3.23 & 43.55 & 6.45 & 33.87 & 9.68 & 30.65 & 14.52 \\
\hline $13,001-14,400$ & 8.19 & 6.55 & 32.79 & 13.11 & 21.31 & 18.03 & 21.31 & 19.67 \\
\hline$\geq 17,201$ & 35.71 & 0 & 53.57 & 10.71 & 28.57 & 14.29 & 39.29 & 14.29 \\
\hline \multicolumn{9}{|l|}{ Area-2B } \\
\hline$\leq 4,500$ & $20.00^{f}$ & 0 & 60.00 & 0 & 50.00 & 10.00 & 40.00 & 0 \\
\hline $4,501-6,000$ & 15.22 & 2.17 & 51.09 & 5.43 & 34.78 & 9.78 & 40.22 & 11.96 \\
\hline $6,001-7,000$ & 8.86 & 10.13 & 32.91 & 13.92 & 26.58 & 16.46 & 25.32 & 20.25 \\
\hline $7,001-8,500$ & 13.85 & 3.08 & 35.38 & 9.23 & 20.00 & 9.23 & 21.54 & 13.55 \\
\hline
\end{tabular}

aWBS-14 = Warner-Bratzler shear force value $(\mathrm{kg})$ at $14 \mathrm{~d}$ (14) postmortem.

${ }^{\mathrm{b} M F T}=$ muscle fiber tenderness rating $(8=$ extremely tender; $1=$ extremely tough).

${ }^{\mathrm{C}} \mathrm{CTA}=$ connective tissue amount rating ( $8=$ none; $1=$ abundant).

${ }^{\mathrm{d} O T}=$ overall tenderness rating ( $8=$ extremely tender; $1=$ extremely tough).

epercentage of all the carcasses for each Tendertec output variable Area-2 reading that have steaks with a Warner-Bratzler shear values $1.706 \mathrm{~kg}$.

fPercentage of all the carcasses for each Tendertec output variable Area-2B reading that have steaks with a Warner-Bratzler shear value $\leq$ $1.706 \mathrm{~kg}$.

only Tendertec output variables in a three-variable regression equation explained just $2 \%$ of the observed variation in overall tenderness ratings.

These results suggest that the Tendertec probe may be capable of detecting contributions of amount of connective tissue to the tenderness of beef steaks, the effects of which are slight in youthful carcasses and dissipate with cooking as collagen softening and gelatinization occurs (Visser et al., 1960). Alsmeyer et al. (1966) and Carpenter et al. (1965) found low associations between raw beef muscle tenderness values and the tenderness of cooked beef samples.

\section{Implications}

As has been reported for Tendertec's predecessors, tenderness prediction capabilities (accuracy) of this instrument seem limited because of the changes that occur in muscles during the cooking process.

Table 7. Segregation analysis based on carcass expert grader quality grade for steak shear force values and steak sensory panel ratings

\begin{tabular}{lcccc}
\hline \hline & \multicolumn{2}{c}{ Expert grader quality grade } & & \\
\cline { 2 - 3 } Trait & Select & Choice & P & SE \\
\hline WBS-14 $^{\mathrm{b}}$ & $2.53^{\mathrm{h}}$ & $2.29^{\mathrm{i}}$ & .007 & .688 \\
WBS-28 $^{\mathrm{b}}$ & $2.23^{\mathrm{h}}$ & $2.04^{\mathrm{i}}$ & .006 & .530 \\
MFT $^{\mathrm{c}}$ & $4.66^{\mathrm{i}}$ & $5.08^{\mathrm{h}}$ & .001 & .787 \\
CTA $^{\mathrm{d}}$ & $4.55^{\mathrm{k}}$ & $4.77^{\mathrm{j}}$ & .023 & .749 \\
OT $^{\mathrm{f}}$ & $4.43^{\mathrm{i}}$ & $4.82^{\mathrm{h}}$ & .001 & .817 \\
JUI $^{\mathrm{f}}$ & 4.78 & 4.85 & .183 & .413 \\
FI $^{\mathrm{g}}$ & 4.87 & 4.90 & .391 & .244 \\
\hline
\end{tabular}

${ }^{a}$ Carcasses assigned quality grades of Standard or Prime were excluded from the analysis because of low numbers of carcasses in those quality grades.

bWBS =Warner-Bratzler shear force value $(\mathrm{kg})$ at $14 \mathrm{~d}(14)$ postmortem or at $28 \mathrm{~d}(28)$ postmortem.

CMFT $=$ Muscle fiber tenderness rating ( $8=$ extremely tender; $1=$ extremely tough $)$.

${ }^{\mathrm{d}} \mathrm{CTA}=$ connective tissue amount rating ( $8=$ none; $1=$ abundant).

eOT $=$ overall tenderness rating ( $8=$ extremely juicy; $1=$ extremely tough).

fJ UI = juiciness rating ( 8 = extremely juicy; 1 = extremely dry).

${ }_{\mathrm{F}} \mathrm{FI}=$ flavor intensity rating ( $8=$ extremely intense; $1=$ extremely bland $)$.

h,i Means within a row lacking a common superscript letter differ $(\mathrm{P}<.01)$.

$j, \mathrm{k}$ Means within a row lacking a common superscript letter differ $(\mathrm{P}<.05)$. 
Table 8. Regression models for steak overall tenderness ratings using carcass Tendertec output variables, carcass expert grader quality grade, and carcass expert grader quality grade factors

\begin{tabular}{|c|c|c|c|}
\hline \multicolumn{3}{|c|}{ Independent variable } & $\mathrm{R}^{2}$ \\
\hline \multicolumn{3}{|c|}{ Expert grader Marblinga } & .040 \\
\hline \multicolumn{3}{|c|}{ Expert grader $\mathrm{QG}^{\mathrm{b}}$} & .039 \\
\hline \multicolumn{3}{|c|}{ Expert grader LMATC } & .034 \\
\hline \multicolumn{3}{|c|}{ Expert grader SMAT ${ }^{d}$} & .014 \\
\hline \multicolumn{3}{|l|}{ Tendertec Area- $2^{\mathrm{e}}$} & .014 \\
\hline \multicolumn{3}{|l|}{ Tendertec Area-2B } & .017 \\
\hline \multicolumn{3}{|l|}{ Tendertec Power-2 $2^{e}$} & .003 \\
\hline \multicolumn{3}{|l|}{ Tendertec Power-2B ${ }^{\mathrm{e}}$} & .004 \\
\hline Tendertec Area-2 & \multicolumn{2}{|l|}{ Expert grader Marbling } & .061 \\
\hline Tendertec Area-2 & \multicolumn{2}{|l|}{ Expert grader QG } & .058 \\
\hline Tendertec Area-2B & \multicolumn{2}{|l|}{ Expert grader LMAT } & .044 \\
\hline Tendertec Area-2B & \multicolumn{2}{|l|}{ Expert grader Marbling } & .058 \\
\hline Tendertec Area-2B & \multicolumn{2}{|l|}{ Expert grader QG } & .058 \\
\hline Tendertec Area-2 & Expert grader Marbling & Expert grader SMAT & .096 \\
\hline Tendertec Area-2 & Expert grader Marbling & Expert grader LMAT & .085 \\
\hline Tendertec Area-2B & Expert grader Marbling & Expert grader SMAT & .093 \\
\hline Tendertec Area-2B & Expert grader Marbling & Expert grader LMAT & .083 \\
\hline Tendertec Area- 2 & Tendertec Area-2B & Expert grader Marbling & .062 \\
\hline Tendertec Area-2 & Tendertec Area-2B & Tendertec Power-2 & .020 \\
\hline
\end{tabular}

${ }^{\mathrm{a}}$ Expert grader marbling = average carcass marbling score of three expert graders.

bExpert grader QG = average quality grade as assessed by three expert graders.

'Expert grader LMAT = average carcass lean maturity as assessed by three expert graders.

dExpert grader SMAT = average carcass skeletal maturity as assessed by three expert graders.

'Tendertec probe output variables: Area-2, Area-2B, Power-2, and Power-2B.

\section{Literature Cited}

Alsmeyer, R. H., J . W. Thornton, R. L. Hiner, and N. C. Bollinger. 1966. Beef and pork tenderness measured by the press, Warner-Bratzler and STE methods. Food Technol. 20:115.

Briskey, E. J., and R. W. Bray. 1964. A Special Study of the Beef Grade Standards. Report submitted to the American National Cattlemen's Association, Denver, CO.

Carpenter, Z. L., R. G. Kauffman, R. W. Bray, and K. G. Weckel. 1965. Objective and subjective measures of pork quality. Food Technol. 19:118.

Cross, H. R., R. Moen, and M. S. Stanfield. 1978. Training and testing judges for sensory analysis of meat quality. Food Technol. 32:48.

Gordon, T. 1994. The Tendertec approach to determine important carcass attributes. National Beef Instrument Assessment Plan. May 25-26, 1994. National Live Stock and Meat Board, Chicago, IL.

Harris, J . J ., and J. W. Savell. 1993. I mpact of carcass maturity on the tenderness of beef from young cattle. Backgrounder ( $\mathrm{J}$ uly issue). Department of Animal Sciences, Texas A \& M University, College Station.

J ones, B. K., and J . D. Tatum. 1994. Predictors of beef tenderness among carcasses produced under commercial conditions. J . Anim. Sci. 72:1492.

Koohmariae, M. 1992. Role of the neutral proteinases in postmortem muscle protein degradation and meat tenderness. Proc. Recip. Meat Conf. 45:63.

National Cattlemen's Association. 1994. National Beef Tenderness Symposium, Executive Summary. April 22-23, 1994, Denver, CO. National Cattlemen's Association, Englewood, CO.
National Live Stock and Meat Board. 1994. National Beef Instrument Assessment Plan, Executive Summary. May 25-26, 1994. National Live Stock and Meat Board, Chicago, IL.

Parrish, F. C. 1974. Relationship of marbling to meat tenderness. Proc. Meat Ind. Res. Conference. pp 117-131.

SAS. 1991. SAS Users Guide: Statistics. (Version 6, 4th Ed.). SAS Inst. Inc., Cary, NC.

Smith, G. C., G. R. Culp, and Z. L. Carpenter. 1978. Postmortem aging of beef carcasses. J. Food. Sci. 43:823.

Smith, G. C., J . W. Savell, R. P. Clayton, T. G. Field, D. B. Griffin, D. S. Hale, M. F. Miller, T. H. Montgomery, J. B. Morgan, J. D. Tatum, J. W. Wise, D. L. Wilkes, and C. D. Lambert. 1992. Improving the consistency and competitiveness of beef. The Final Report of the National Beef Quality Audit-1991. pp 1-237. National Cattlemen's Association, Englewood, CO.

Stanton, C., and N. Light. 1988. The effects of conditioning on meat collagen: Part 2-Direct biochemical evidence for proteolytic damage in insoluble perimysial collagen after conditioning. Meat Sci. 23:179.

Stanton, C., and N. Light. 1990. The effects of conditioning on meat collagen: Part 3-Evidence for proteolytic damage to endomysial collagen after conditioning. Meat Sci. 27:41.

Swatland, H. J., S. P. Ananthanarayanan, and A. A. Goldenberg 1994. A review of probes and robots: Implementing new technologies in meat evaluation. J. Anim. Sci. 72:1475.

Visser, R. Y., D. L. Harrison, G. E. Goetz, M. Bunyan, M. M Skelton, and D. L. Mackintosh. 1960. The effect of degree of doneness on the tenderness and juiciness of beef cooked in the oven and in deep fat. Food Technol. 14:193.

Wheeler, T. L., L. V. Cundiff, and R. M. Koch. 1994. Effect of marbling degree on beef palatability in Bos taurus and Bos indicus cattle. J. Anim. Sci. 72:3145. 